Article

\title{
High-Load Resistance Exercise Augments Androgen Receptor-DNA Binding and Wnt/ $\beta$-Catenin Signaling without Increases in Serum/Muscle Androgens or Androgen Receptor Content
}

\author{
Thomas D. Cardaci ${ }^{1,2}{ }^{1}$, Steven B. Machek ${ }^{1}$, Dylan T. Wilburn ${ }^{1}$, Jeffery L. Heileson ${ }^{1}(\mathbb{D}$ \\ and Darryn S. Willoughby $1,3, *$ \\ 1 Department of Health, Human Performance and Recreation, Robbins College of Health \\ and Human Sciences, Baylor University, Waco, TX 76706, USA; tcardaci@email.sc.edu (T.D.C.); \\ steven_machek2@baylor.edu (S.B.M.); dylan_wilburn1@baylor.edu (D.T.W.); \\ jeffery_heileson@baylor.edu (J.L.H.) \\ 2 Department of Exercise Science, Arnold School of Public Health, University of South Carolina, Columbia, \\ SC 29208, USA \\ 3 School of Exercise and Sport Science, Mayborn College of Health Sciences, University of Mary \\ Hardin-Baylor, Belton, TX 76513, USA \\ * Correspondence: dwilloughby@umhb.edu
}

Received: 20 November 2020; Accepted: 10 December 2020; Published: 15 December 2020

\begin{abstract}
The purpose of this study was (1) to determine the effect of single bouts of volume- and intensity-equated low- (LL) and high-load (HL) full-body resistance exercise (RE) on AR-DNA binding, serum/muscle testosterone and dihydrotestosterone, muscle androgen receptor (AR), and AR-DNA binding; and, (2) to determine the effect of RE on sarcoplasmic and nucleoplasmic $\beta$-catenin concentrations in order to determine their impact on mediating AR-DNA binding in the absence/presence of serum/muscle androgen and AR protein. In a cross-over design, 10 resistance-trained males completed volume- and intensity-equated LL and HL full-body RE. Blood and muscle samples were collected at pre-, $3 \mathrm{~h}$-, and $24 \mathrm{~h}$ post-exercise. Separate $2 \times 3$ factorial analyses of variance (ANOVAs) with repeated measures and pairwise comparisons with a Bonferroni adjustment were used to analyze the main effects. No significant differences were observed in muscle $\mathrm{AR}$, testosterone, dihydrotestosterone, or serum total testosterone in either condition $(p>0.05)$. Serum-free testosterone was significantly decreased $3 \mathrm{~h}$ post-exercise and remained significantly less than baseline $24 \mathrm{~h}$ post-exercise in both conditions $(p<0.05)$. In response to HL, AR-DNA binding significantly increased at $3 \mathrm{~h}$ post-exercise $(p<0.05)$, whereas no significant differences were observed at any time in response to LL $(p>0.05)$. Moreover, sarcoplasmic $\beta$-catenin was significantly greater in HL $(p<0.05)$ without significant changes in nucleoplasmic $\beta$-catenin $(p>0.05)$. In conclusion, increases in AR-DNA binding in response to HL RE indicate AR signaling may be load-dependent. Furthermore, despite the lack of increase in serum and muscle androgens or AR content following HL RE, elevations in AR-DNA binding with elevated sarcoplasmic $\beta$-catenin suggests $\beta$-catenin may be facilitating this response.
\end{abstract}

Keywords: androgen receptor; $\beta$-catenin; skeletal muscle; cell signaling; Wnt signaling; hypertrophy; resistance exercise; testosterone; dihydrotestosterone; load

\section{Introduction}

Androgens, such as testosterone and dihydrotestosterone (DHT), play a pivotal role in muscle specific gene and protein expression, which can ultimately lead to skeletal muscle hypertrophy [1]. 
Primarily, androgens exert their anabolic effects through the bloodstream where they interact with androgen receptors (AR) in skeletal muscle. Specifically, free/unbound testosterone diffuses across the sarcolemma in skeletal muscle, where a portion is converted to the more biologically active DHT (relative greater AR binding affinity and reduced disassociation rate) by the enzyme, $5 \alpha$-reductase [2,3]. Once bound by the androgen, the activated AR undergoes a conformational change causing a dissociation from the heterocomplex of heat shock proteins and other co-chaperones, ultimately resulting in dimerization. After dissociation, it is then considered an active AR complex and is translocated into the nucleus where it binds to the androgen response element (ARE) upstream of AR gene promoter regions. The AR gene, the p21 cyclin-dependent kinase inhibitor protein 1 gene, and the insulin-like growth factor-1 gene have all been found to contain AREs [4]. This AR-DNA binding results in up-regulation of these genes (and others) which play significant roles in skeletal muscle anabolism and contribute to hypertrophy of the muscle [5].

It is thought that the acute increase in serum/muscle androgen and/or AR content are responsible for the up-regulation in AR signaling. While this has been reported [4,6-17], AR activation and subsequent DNA-binding has been shown to increase in response to resistance exercise (RE) independent of an androgenic response as well [18-24]. Additionally, acute AR mRNA and/or protein expression in response to RE has been shown to increase $[17,18,25]$, decrease or not change in a number of studies [6,13,23,25-28]. This suggests that increases in AR signaling may not be primarily dependent on rises in androgens or AR protein concentrations. However, just as relevant, the variety of methodological approaches between RE protocols may be influencing the differential results.

Recent research suggests increases in AR signaling in response to mechanical loading may be due to up-regulation in specific AR-interacting proteins $[23,29,30]$. AR-interacting proteins may increase AR signaling by modulating AR binding affinity and/or AR activation via ligand-dependent or -independent processes [31,32]. Specifically, $\beta$-catenin, an important multifunctional protein involved in wingless-type mouse mammary tumor virus integration site (Wnt) signaling, has been shown to be a transcriptional co-activator of the AR [33-35]. Mechanistically, $\beta$-catenin concentrations increase within the sarcoplasm in response to a series of regulatory steps. This process involves: (1) the binding of a Wnt ligand to the extracellular cysteine rich domain on the transmembrane Frizzled receptor, (2) phosphorylation/activation of the protein disheveled by low-density lipoprotein receptor-related protein (LDLR-LRP) -5 or -6 co-receptors, (3) blocking of glycogen synthase kinase- $3 \beta$ activity (GSK-3 $\beta$ ) by sequestering GSK-3 $\beta$ via the inhibitory protein frequently rearranged in advanced T cell lymphomas (Frat), and (4) inactivation of the "destruction complex" resulting in decreased phosphorylation and down-regulating proteasomal degradation of $\beta$-catenin [36-39]. This leads to armadillo repeats 1-6 of $\beta$-catenin to interact with the activation function-2 (AF-2) region (within the ligand-binding domain (LBD)) to facilitate LBD-NTD interactions and the ensuing formation of a "ligand-binding pocket" and/or stabilization of the bound androgen [32,34,39-41]. Following $\beta$-catenin-mediated activation, the AR complex translocates into the nucleus where it binds to the ARE on the target gene up-regulating muscle specific gene expression, which in turn can play an important regulatory role in skeletal muscle growth. Currently, there are extremely limited data investigating $\beta$-catenin-AR interactions in RE models. Thus far, the existing data suggest that $\beta$-catenin-mediated AR signaling does appear to be responsive to RE [23,42]. However, $\beta$-catenin's response to various $R E$ design variables and the specific mechanisms remain largely unexplored.

It is generally thought that higher volume and intensity RE are needed to elicit an appropriate stimulus for increasing AR signaling activity. While this may be the case, RE load may be the key variable responsible for increasing AR activity, provided it is accompanied with appropriate training volume and intensity. This is due to the overwhelming role load has on recruitment of motor units and the subsequent fiber type-specific metabolic and/or contractile stress placed on skeletal muscle. However, research investigating the load's impact on muscular adaptations is commonly misinterpreted due to suboptimal methodological approaches and inconsistencies in terminology. For example, much of the literature does not clearly define and differentiate between intensity and 
load. In RE, intensity is commonly defined as a percent of 1 repetition maximum (1 RM) [43]. However, it is more appropriate to define this as "load". Intensity may be more appropriately defined as the number of repetitions performed at a given RM [44]. For example, performing 10 repetitions at a $10 \mathrm{RM}$ (which is approximately $75 \%$ of $1 \mathrm{RM}$ ) until volitional failure would be considered an intensity of $100 \%$. These semantic differences and lack of clearly defined variables have contributed to some of the confusion in this area. Furthermore, rarely is the effect of load on skeletal muscle adaptations examined without being affected by confounding variables such as volume or intensity. This is problematic since volume and intensity have both been shown to be important factors influencing androgenic hormone responses following RE [45]. Therefore, the purpose of this study was (1) to determine the effect of single bouts of volume- and intensity-equated low (LL) and high-load (HL) full-body RE on AR-DNA binding, serum/muscle testosterone and DHT, AR muscle protein content, and AR-DNA binding and (2) to determine the effect of on sarcoplasmic and nucleoplasmic $\beta$-catenin concentrations in order to determine their impact on mediating AR-DNA binding in the absence/presence of serum/muscle androgen and AR protein.

\section{Materials and Methods}

\subsection{Experimental Approach}

Participants visited the laboratory on 3 separate occasions in the following manner: visit $1=$ entry/familiarization, medical/physical activity screening, and RE max testing; visit $2=\mathrm{LL}$ (50\% $1 \mathrm{RM})$ RE; visit $3=$ HL ( $80 \% 1 \mathrm{RM})$ RE session. Each visit was 7-10 days following the previous visit and participants were instructed to refrain from exercise for $48 \mathrm{~h}$ prior to RE max testing and RE protocols. In a crossover design and volume-equated manner, participants performed identical full-body RE consisting of barbell bench press, angled leg press, lat pulldown, and unilateral leg extension. During LL RE, participants performed $50 \%$ of their one repetition maximum to volitional failure for 4 sets in each exercise. Total exercise load volume (sets $\times$ repetitions $\times$ load) was calculated and equated in the HL RE during visit 3. During HL, sets were performed until participants reached the volume in order to match the total volume performed during LL. This allowed for volume and intensity to be equated between the two conditions. Each session involved the gathering of data for the analysis of biochemical and hormonal markers of blood and muscle metabolite changes.

\subsection{Participants}

Ten apparently healthy, recreationally resistance-trained (regular, consistent resistance training (i.e., thrice weekly) for at least 1 year prior to the onset of the study) men between the ages of 18-35 volunteered for this study. Resistance training status was confirmed by a leg press 1-RM, which was compared to normal strength-to-body weight ratios. Participants were eligible for inclusion if their strength-to-body weight ratio was $\geq 2.82$ times body weight [46]. Participants were also included if they were at low risk for cardiovascular disease with no contraindications to exercise as outlined by the American College of Sports Medicine (ACSM) and had not consumed any nutritional supplements (excluding multi-vitamins) one month prior to the study. All eligible participants signed university-approved informed consent documents and received a written and verbal explanation of the study design. All study procedures were approved by the Institutional Review Board at Baylor University (approval \#1521229-3) and conformed to the ethical consideration of the Declaration of Helsinki. Mean $( \pm \mathrm{SD})$ participant descriptive information (anthropometrics, baseline health assessments, resistance training experience) are found in Table 1. 
Table 1. Mean ( \pm standard deviation (SD)) descriptive information of all participants, anthropometrics, health markers, and resistance exercise related variables.

\begin{tabular}{cc}
\hline Descriptive & Mean $( \pm$ SD) \\
\hline Sample Size & 10 \\
Age (year) & $23.2( \pm 4.68)$ \\
Height $(\mathrm{cm})$ & $176.78( \pm 0.58)$ \\
Total Body Mass $(\mathrm{kg})$ & $87.15( \pm 5.77)$ \\
Lean Body Mass $(\mathrm{kg})$ & $70.66( \pm 6.62)$ \\
Bone Mineral Content $(\mathrm{kg})$ & $2.87( \pm 0.25)$ \\
Fat Mass $(\mathrm{kg})$ & $13.62( \pm 3.54)$ \\
Body Fat $(\%)$ & $15.73( \pm 4.30)$ \\
Resting Heart Rate $(\mathrm{bpm})$ & $63.6( \pm 9.13)$ \\
Systolic Blood Pressure $(\mathrm{mmHg})$ & $118.2( \pm 5.77)$ \\
Diastolic Blood Pressure $(\mathrm{mmHg})$ & $75.4( \pm 7.66)$ \\
Resistance Training Experience $(\mathrm{year})$ & $4.68( \pm 1.85)$ \\
Leg Press 1 RM $(\mathrm{kg})$ & $464.4( \pm 93.8)$ \\
Barbell Bench Press 1 RM $(\mathrm{kg})$ & $116.8( \pm 12.7)$ \\
\hline
\end{tabular}

$\mathrm{SD}$, standard deviation; $1 \mathrm{RM}$, one-repetition maximum.

\subsection{Resistance Exercise Max Testing}

To determine muscular strength and proper RE load prescription, participants performed 1-RM tests for bench press and angled leg press and 10-RM tests for unilateral leg extension and lat pulldown in accordance with the National Strength and Conditioning Association (NSCA) guidelines. Leg press foot placement and bench press/lat pulldown handgrip width were recorded and held constant over all testing conditions in order to maintain consistency. To ensure participants were moving through the full range of motion during each repetition, a goniometer was used to establish 90 degrees of knee flexion on the leg press. Moreover, during the bench press, participants were instructed to touch their chest with the barbell and extend their elbows to full extension to constitute a completed repetition. Similarly, participants were required to fully extend their elbows and pull the cable attachment until it made contact with their sternum/chest during the lat pulldown as well as fully extend their knees to constitute a completed repetition during the unilateral leg extension.

Participants warmed up by completing 5 to 10 repetitions at approximately $50 \%$ of the estimated $1 \mathrm{RM} / 10 \mathrm{RM}$. Then participants rested for $1 \mathrm{~min}$ and then completed 3 to 5 repetitions at approximately $70 \%$ of the estimated $1 \mathrm{RM} / 10 \mathrm{RM}$. Load was then increased conservatively and the participant attempted to lift the load for 1/10 repetition(s). If the lift was successful, the participant rested for $5 \mathrm{~min}$ before attempting the next weight increment. As per NSCA guidelines, load was increased by $2.5-5 \%$ for upper body exercises and by $5-10 \%$ for lower body exercises. This procedure was continued until the participant failed to complete the lift. The $1 \mathrm{RM} / 10 \mathrm{RM}$ was recorded as the maximum weight that the participant was able to lift for $1 / 10$ repetition(s).

\subsection{Resistance Exercise Protocol}

During visits 2 and 3 participants performed full-body RE protocols consisting of barbell bench press, angled leg press, lat pulldown, and unilateral leg extension. As our main experimental variable, load varied between LL and HL RE while keeping all other controllable variables constant. During LL RE, participants performed 3 sets of each exercise at 50\% $1 \mathrm{RM}$ and were taken to volitional failure following the previously described warm-up protocol. During HL RE, participants performed each exercise at $80 \% 1 \mathrm{RM}$ to volitional failure. Additionally, volume was equated between the two visits. Due to the greater amount of volume that can be accumulated with a lighter load, additional sets for each exercise were utilized (if necessary) in order to equate volume between LL and HL conditions. Moreover, when fatigue/failure occurred, study personnel provided assistance to help re-rack the weight safely. In all cases, $2-4$ min rest occurred between all sets and exercises. Due to the diurnal nature and dietary influence of the biomarkers being investigated, participants reported 
to the laboratory upon waking and in a fasted state at 08:53 $( \pm 0: 55)$ and 08:37 $( \pm 1: 00)$ for LL and HL, respectively. Moreover, in order to minimize nutritional mediation of the markers we were investigating, participants received a standardized nutrition bar 30 min prior to RE (Power Bar ${ }^{\circledR}$, Premier Nutrition Corporation, Kings Mountain, NC, USA, (carbohydrate: 25 g, protein: 20 g, fat: 6 g, fiber: $4 \mathrm{~g}$ )). Additionally, as auxiliary measures of exercise intensity, muscle soreness and a rating of perceived of exertion (RPE) of each condition was gathered. Muscle soreness was assessed pre-exercise, $3 \mathrm{~h}$ post-, and $24 \mathrm{~h}$ post-exercise via a visual analogue scale in which participants were instructed to draw an intersecting mark across a $13-\mathrm{cm}$ scale $(0=$ no soreness, $13=$ extreme soreness). The distance of each mark was measured from 0 , and the measurement was used as the observed muscle soreness value. RPE was assessed immediately post-exercise via the modified Borg Scale (0-10). Lastly, in an attempt to control for variations in RE performance, skeletal muscle strength, and proper recovery, RE protocols were scheduled within $2 \mathrm{~h}$ of each other and separated by 7-10 days [47].

\subsection{Body Composition, Dietary, and Hydration Analysis}

Total body mass $(\mathrm{kg})$ and height $(\mathrm{cm})$ were determined on a standard dual beam balance scale (Detecto Bridgeview, IL, USA). Percent bone mineral content, body fat, fat mass, and lean body mass were determined using dual-energy X-ray absorptiometry (DEXA) (Hologic Discovery Series W, Waltham, MA, USA). Participants were required to record their dietary intake for $48 \mathrm{~h}$ prior to RE max testing and protocols. Participants' diets were not be standardized but were asked to keep their dietary habits consistent throughout the study. The dietary recalls were evaluated with the MyFitnessPal mobile or desktop application (Under Armor Inc., Baltimore, MD, USA) to determine the average daily macronutrient consumption of fat, carbohydrate, and protein in the diet for the duration of the study. Since previous research has demonstrated individuals who are dehydrated will have an attenuated testosterone response with RE [48] and to account for shifts in plasma volume, prior to the max testing and RE protocols, total body water using bioelectrical impedance analysis (Tanita, Tokyo, Japan) and packed cell volume were assessed.

\subsection{Muscle Biopsies}

Percutaneous muscle biopsies ( $30 \mathrm{mg})$ were obtained from the middle portion of the vastus lateralis muscle of the dominant leg (midpoint between the patella and the greater trochanter of the femur) at a depth between 1 and $2 \mathrm{~cm}$ using the fine needle aspiration technique. Muscle tissue was extraction using the TRU-CORE ${ }^{\circledR} 1$ Automatic Biopsy Instrument (Angiotech, Medical Device Technologies, Inc., Gainsville, FL, USA) after subcutaneous administration of the local anesthetic (1 mL of $1 \%$ lidocaine/xylocaine). After the initial biopsy, the following biopsy attempts were made to extract tissue from approximately the same location as the initial biopsy by using the pre-biopsy scar, depth markings on the needle, and a successive incision that was made approximately $0.5 \mathrm{~cm}$ to the former from medial to lateral. After removal, adipose tissue was trimmed from the muscle specimens and was immediately frozen and stored at $-80^{\circ} \mathrm{C}$ for later analysis. Three muscle samples were obtained at visits 2 and 3 for a total of 6 muscle biopsies performed during the course of the study. Biopsies were taken pre-exercise and at 3 and $24 \mathrm{~h}$ post-exercise during visits 2 and 3.

\subsection{Venipuncture}

Venous blood samples were obtained into $10 \mathrm{~mL}$ vacutainer tubes using a 21-gauge phlebotomy needle inserted into the antecubital vein. Blood samples stood at room temperature for $10 \mathrm{~min}$ and then centrifuged. The serum was then removed and frozen at $-80{ }^{\circ} \mathrm{C}$ for later analysis. Six blood samples were obtained during the course of the study. The blood samples were collected pre-exercise and at 3 and $24 \mathrm{~h}$ post-exercise during visits 2 and 3. 


\subsection{Skeletal Muscle Total, Sarcoplasmic, and Nucleoplasmic Protein Extraction}

A portion of each muscle sample was weighed and homogenized using a commercial tissue extraction reagent (Invitrogen Corporation, Camarillo, CA, USA) and a tissue homogenizer. Following total protein extraction, total sarcoplasmic and nucleoplasmic proteins were isolated separately using cytoplasmic and nuclear extraction buffers (Aviva Systems Biology Corporation, San Diego, CA, USA). All extracts were supplemented with phenylmethanesulfonyl fluoride and a protease inhibitor cocktail (Sigma Chemical Company, St. Louis, MO, USA) with broad specificity for the inhibition of serine, cysteine, and metallo-proteases. Protein contents for total protein, sarcoplasm-, and nuclear-extracted samples were analyzed in duplicate and determined spectrophotometrically at a wavelength of $750 \mathrm{~nm}$ (Bio-Rad Hercules, CA, USA) and using bovine serum albumin as the standard [49].

\subsection{Serum Total and Free Testosterone Analysis}

The concentrations of serum total and free testosterone were assessed via commercially-available enzyme-linked immunosorbent assay (ELISA) kits (Eagle Biosciences Incorporation, Nashua, NH, USA). The specificity of these kits are $100 \%$ with the sensitivity estimated to be $0.022 \mathrm{ng} / \mathrm{mL}$ and $0.018 \mathrm{pg} / \mathrm{mL}$, respectively, for total and free testosterone. Samples were analyzed in duplicate and absorbances were read at a wavelength of $450 \mathrm{~nm}$. Unknown concentrations were determined by linear regression against known standard curves using commercial software (Microplate Manager, Bio-Rad, Hercules, CA, USA). The overall intra-assay percent coefficients of variation were $2.37 \%( \pm 2.54)$ and $2.1 \%( \pm 1.98)$ and, respectively, for total and free testosterone.

\subsection{Intramuscular Testosterone and Dihydrotestosterone (DHT) Analysis}

The same ELISA kit employed for serum free testosterone was used to analyze intramuscular testosterone concentrations. Similarly, intramuscular DHT was assessed using a commercially available ELISA kit (Eagle Biosciences Incorporation, Nashua, NH, USA). These assays were performed using the total muscle protein cellular extracts $[23,28]$. The specificity of the free testosterone and DHT ELISA kits were both $100 \%$ with the sensitivity estimated to be $0.018 \mathrm{pg} / \mathrm{mL}$ and $6 \mathrm{pg} / \mathrm{mL}$, respectively. All samples were analyzed in duplicate and absorbances were determined at a wavelength of $450 \mathrm{~nm}$ using a microplate reader (iMark, Bio-Rad, Hercules, CA, USA) against known standard curves, and final concentrations expressed relative to total protein concentration. The overall intra-assay percent coefficients of variation were $1.31 \%( \pm 1.15)$ and $3.35 \%( \pm 2.71)$, respectively, for intramuscular testosterone and DHT.

\subsection{Intramuscular Androgen Receptor Analysis}

Total AR protein content was assessed in total muscle protein cellular extracts via commercially available ELISA kits (MyBioSource Incorporation, San Diego, CA, USA). The assay is 100\% specific and has a sensitivity of $0.1 \mathrm{ng} / \mathrm{mL}$. All samples were analyzed in duplicate and absorbances were determined at a wavelength of $450 \mathrm{~nm}$ using a microplate reader (iMark, Bio-Rad, Hercules, CA, USA) against known standard curves, and final concentrations expressed relative to total protein concentration. The overall intra-assay percent coefficient of variation was $7.91 \%( \pm 6.64)$.

\subsection{Androgen Receptor-DNA Binding Analysis}

AR-DNA binding was quantified in nucleoplasmic extracts by a commercially available ELISA kit (Aviva Systems Biology Corporation, San Diego, CA, USA). This particular immunoassay utilizes the qualitative technique of an indirect ELISA and the incorporation specific double-stranded (dsDNA) oligonucleotides (representing the ARE ( $5^{\prime}$-AGAACA-3 $\left.3^{\prime}\right)$ ). The assay is $100 \%$ specific and has a sensitivity of $0.3 \mu \mathrm{g}$ of AR-DNA binding in nuclear-extracted MCF7 cells. All samples were analyzed in duplicate and absorbances were determined at a wavelength of $450 \mathrm{~nm}$ using a microplate reader 
(iMark, Bio-Rad, Hercules, CA, USA). Absorbances were then expressed relative to total nucleoplasmic protein content. The overall intra-assay percent coefficient of variation was $9.89 \%( \pm 7.59)$.

\subsection{Sarcoplasmic and Nucleoplasmic $\beta$-Catenin Analysis}

Sarcoplasmic and nucleoplasmic $\beta$-catenin were assessed via commercially available ELISA kits (Biovision Incorporated, Milpitas, CA, USA) and performed using the sarcoplasmic and nucleoplasmic extracts. The assay is $100 \%$ specific and has a sensitivity of $0.156 \mathrm{ng} / \mathrm{mL}$. All samples were analyzed in duplicate and absorbances were determined at a wavelength of $450 \mathrm{~nm}$ using a microplate reader (iMark, Bio-Rad, Hercules, CA, USA) against known standard curves, and final concentrations expressed relative to sarcoplasmic and nucleoplasmic protein concentration, respectively. The overall intra-assay percent coefficient of variation was $9.79 \%( \pm 6.86)$ and $9.04 \%( \pm 7.70)$, respectively.

\subsection{Statistical Analysis}

Statistical analysis for serum and muscle hormone concentrations, protein metabolite concentrations, and AR-DNA binding activity were performed by utilizing separate $2 \times 3$ (Condition $(\mathrm{LL}, \mathrm{HL}) \times$ Time (Pre-exercise, 3-h Post-exercise, and 24-h Post-exercise)) factorial analyses of variance (ANOVAs) with repeated measures. Given significant baseline value differences, an ANCOVA was used to with the aforementioned baseline data as a covariate. If a significant interaction was found, simple effects analysis was conducted to determine where the interaction occurred. If a significant interaction was present, analysis of main effects was conducted using the simple effects, pairwise comparisons with a Bonferroni adjustment to compare dependent variables within each independent variable condition. If no interaction was present, then normal pairwise comparisons with a Bonferroni adjustment were used to test main effects. The magnitude of statistical significance was measured by effect size (partial Eta-squared), which estimates the ratio of variance in the dependent variable that is explained by the independent variable. Partial Eta Squared effect sizes $\left(\eta^{2}\right)$ are characterized $0.1-0.3$ as small, $0.3-0.5$ as medium, and $\geq 0.5$ as large [50]. All statistical procedures were performed using SPSS 27.0 software and an alpha level of $\leq 0.05$ was set for all statistical measures.

\section{Results}

\subsection{Dietary Analysis and Hydration Status}

The results of the separate one way repeated measures ANOVAs indicated that there was no significant difference in total calories $\left(\mathrm{F}=1.973, p=0.194, \eta^{2}=0.180\right)$ or carbohydrate $(\mathrm{F}=1.690$, $\left.p=0.213, \eta^{2}=0.158\right)$, protein $\left(F=0.805, p=0.462, \eta^{2}=0.082\right)$, fat $\left(F=1.532, p=0.243, \eta^{2}=0.145\right)$, or fiber intake $\left(F=0.395, p=0.680, \eta^{2}=0.047\right)$ between the max testing, LL, or HL conditions. Similarly, total body water did not significantly change $\left(F=1.521, p=0.285, \eta^{2}=0.276\right)$ between the max testing, LL, or HL conditions. For packed cell volume, no significant main effect for time $(\mathrm{F}=1.257, p=0.299$, $\left.\eta^{2}=0.077\right)$ or condition $\left(F=0.242, p=0.630, \eta^{2}=0.016\right)$ was observed between conditions.

\subsection{Resistance Exercise Volume, Rating of Perceived Exertion, and Muscle Soreness}

The results of the separate pair samples $t$-tests indicated no significant differences between conditions in the volumes for leg press $(t=0.482, p=0.641)$, barbell bench press $(t=-0.233, p=0.821)$, lat pulldown $(t=1.297, p=0.227)$, single leg extension $(t=-0.860, p=0.412)$, and total testing session $(t=-0.482, p=0.641)$, or RPE $(t=1.279, p=0.237)$. Additionally, no significant main effect for condition $\left(\mathrm{F}=0.813, p=0.380, \eta^{2}=0.046\right)$ or significant interaction for time and condition $(\mathrm{F}=0.396, p=0.676$, $\left.\eta^{2}=0.023\right)$ for muscle soreness were observed. However, a significant main effect for time $(\mathrm{F}=10.983$, $\left.p<0.001, \eta^{2}=0.392\right)$ was observed. Specifically, analysis revealed a significant increase in muscle soreness at $3 \mathrm{~h}$ post- $(p=0.003)$ and $24 \mathrm{~h}$ post-exercise $(p=0.001)$ compared to pre-exercise. 


\subsection{Serum Total and Free Testosterone Concentration}

The means $( \pm \mathrm{SE})$ for serum total and free testosterone for each condition are indicated in Figure 1 and Table 2. No significant main effect of condition $\left(F=4.421, p=0.103, \eta^{2}=0.525\right)$ or significant time and condition interaction $\left(\mathrm{F}=0.718, p=0.517, \eta^{2}=0.152\right)$ for serum total testosterone concentrations were observed. However, a significant main effect for time $\left(F=6.386, p=0.022, \eta^{2}=0.615\right)$ was observed, which was revealed to be non-significant after adjusting for alpha level inflation via a Bonferroni adjustment $(p=0.091)$.

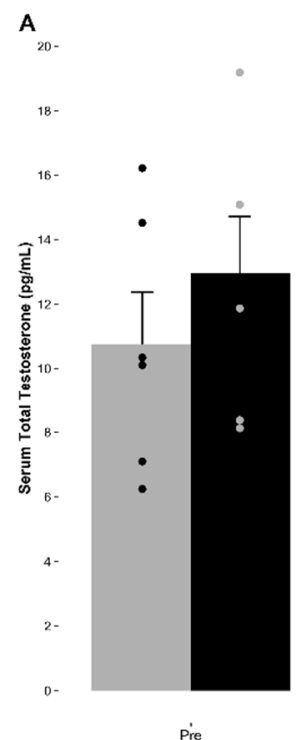

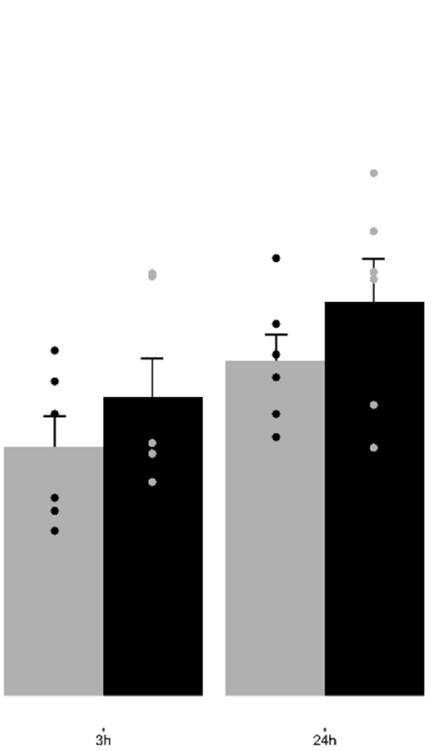

$2 \dot{4 h}$

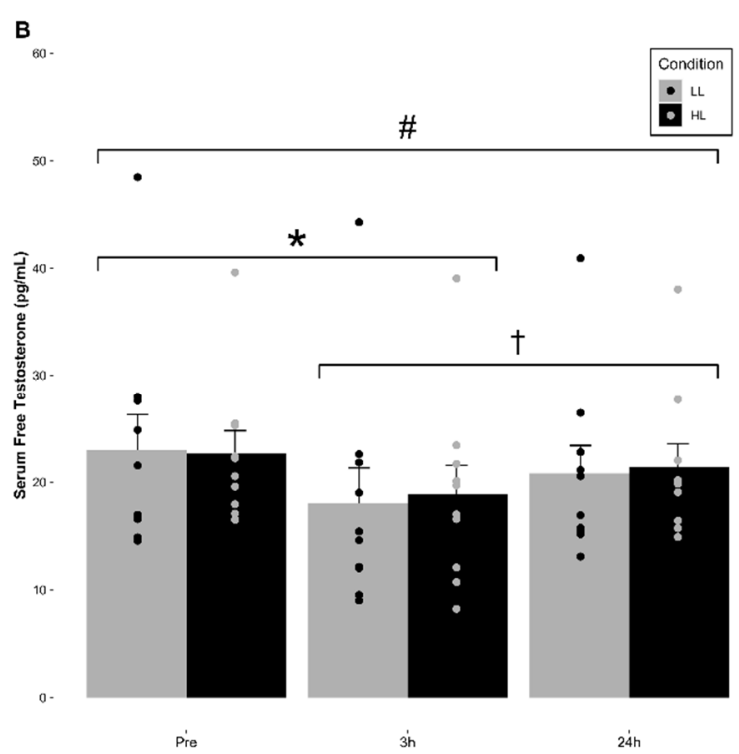

24 '

Figure 1. Mean $( \pm \mathrm{SE})$ and individual changes in serum $(\mathbf{A})$ total testosterone and $(\mathbf{B})$ free testosterone concentrations in response to volume- and intensity-equated low- and high-load resistance exercise. (A): There were no significant changes over time, between conditions, or significant interactions observed $(p>0.05)$. (B): * Indicates a significant decrease at $3 \mathrm{~h}$ post-exercise compared to pre-exercise values in both conditions $(p<0.05)$. " Indicates a significant decrease at $24 \mathrm{~h}$ post-exercise compared to pre-exercise values in both conditions $(p<0.05) .{ }^{+}$Indicates $24 \mathrm{~h}$ post-exercise was significantly greater than $3 \mathrm{~h}$ post-exercise values in both conditions $(p<0.05)$.

Regarding serum free testosterone, no significant main effect of condition $(\mathrm{F}=0.097, p=0.763$, $\left.\eta^{2}=0.011\right)$ or significant time and condition interaction $\left(F=0.611, p=0.554, \eta^{2}=0.064\right)$ for serum free testosterone concentrations were observed. However, a significant main effect for time $(F=21.736$, $\left.p<0.001, \eta^{2}=0.707\right)$ was observed. Pairwise comparisons revealed that there was a significant decrease in serum free testosterone concentrations at $3 \mathrm{~h}$ post-exercise compared to pre-exercise $(p<0.001)$ in both conditions. Additionally, $24 \mathrm{~h}$ post-exercise was significantly greater than $3 \mathrm{~h}$ post-exercise $(p=0.041)$ but did not return to pre-exercise baseline values $(p=0.029)$ in either condition.

\subsection{Intramuscular Testosterone and DHT Concentration}

The means $( \pm \mathrm{SE})$ for intramuscular testosterone and DHT for each condition are indicated in Figure 2 and Table 2. No significant main effect of time $\left(F=0.451, p=0.644, \eta^{2}=0.048\right)$, condition $\left(\mathrm{F}=0.643, p=0.443, \eta^{2}=0.067\right)$, or significant time and condition interaction $(\mathrm{F}=0.777, p=0.475$, $\left.\eta^{2}=0.079\right)$ for intramuscular testosterone concentrations were observed. For intramuscular DHT, no significant main effect of time $\left(\mathrm{F}=0.350, p=0.711, \eta^{2}=0.048\right)$, condition $\left(\mathrm{F}=2.680, p=0.146, \eta^{2}=0.277\right)$, or significant time and condition interaction $\left(\mathrm{F}=0.169, p=0.846, \eta^{2}=0.024\right)$ for intramuscular DHT concentrations were observed. 
Table 2. Mean $( \pm \mathrm{SE})$ of all intramuscular and serum markers of $A R-\beta$-Catenin signaling in response to low- (LL) and high-load (HL) resistance exercise.

\begin{tabular}{|c|c|c|c|}
\hline Condition & Pre-Exercise & 3 h Post & 24 h Post \\
\hline \multicolumn{4}{|c|}{ AR-DNA Binding (Abs/mg) } \\
\hline LL & $0.31( \pm 0.05)$ & $0.26( \pm 0.05)$ & $0.33( \pm 0.05)$ \\
\hline HL & $0.30( \pm 0.04)$ & $0.52( \pm 0.10) *$ & $0.36( \pm 0.08)$ \\
\hline \multicolumn{4}{|c|}{ Sarcoplasmic $\beta$-Catenin (ng/mg) } \\
\hline LL & $8.77( \pm 2.79)$ & $14.38( \pm 4.38)$ & $14.62( \pm 3.96)$ \\
\hline HL & $16.35( \pm 3.62) *$ & $27.09( \pm 4.62) *$ & $29.83( \pm 8.90) *$ \\
\hline \multicolumn{4}{|c|}{ Nucleoplasmic $\beta$-Catenin (ng/mg) } \\
\hline LL & $2.49( \pm 0.42)$ & $2.28( \pm 0.58)$ & $3.23( \pm 0.67)$ \\
\hline HL & $2.65( \pm 0.43)$ & $2.46( \pm 0.50)$ & $1.50( \pm 0.38)$ \\
\hline \multicolumn{4}{|c|}{ Androgen Receptor (ng/mg) } \\
\hline LL & $102.85( \pm 9.46)$ & $74.21( \pm 9.73)$ & $102.92( \pm 19.20)$ \\
\hline HL & $76.20( \pm 6.55)$ & $113.02( \pm 20.45)$ & $98.71( \pm 13.76)$ \\
\hline \multicolumn{4}{|c|}{ Intramuscular TEST (pg/mg) } \\
\hline LL & $0.71( \pm 0.15)$ & $0.57( \pm 0.09)$ & $0.65( \pm 0.08)$ \\
\hline HL & $0.55( \pm 0.05)$ & $0.57( \pm 0.07)$ & $0.61( \pm 0.10)$ \\
\hline \multicolumn{4}{|c|}{ Intramuscular DHT (pg/mg) } \\
\hline LL & $928.32( \pm 76.59)$ & $975.60( \pm 72.34)$ & $1047.05( \pm 113.02)$ \\
\hline HL & $1048.11( \pm 81.79)$ & $1137.32( \pm 111.62)$ & $1190.96( \pm 111.98)$ \\
\hline \multicolumn{4}{|c|}{ Serum Total TEST (pg/mL) } \\
\hline LL & $10.75( \pm 1.62)$ & $7.69( \pm 0.96)$ & $10.39( \pm 0.82)$ \\
\hline HL & $12.95( \pm 1.76)$ & $9.26( \pm 1.21)$ & $12.23( \pm 1.33)$ \\
\hline \multicolumn{4}{|c|}{ Serum Free TEST (pg/mL) } \\
\hline LL & $23.03( \pm 3.25)$ & $18.05( \pm 3.28) *$ & $20.84( \pm 2.58) *$ \\
\hline HL & $22.67( \pm 2.13)$ & $18.86( \pm 2.73)$ * & $21.41( \pm 2.18) *$ \\
\hline
\end{tabular}

Data were analyzed using separate $2 \times 3$ factorial analyses of variance (ANOVAs) with repeated measures and an alpha level of $\leq 0.05$. Protein markers are expressed relative to total protein content of the appropriate cell compartment or total cellular protein content. LL, low load; HL, high load; AR, androgen receptor; TEST, testosterone; DHT, dihydrotestosterone. * Indicates a significant main effect for time, condition, or time and condition interaction $(p<0.05)$

\subsection{Intramuscular Androgen Receptor Protein Content}

The mean $( \pm \mathrm{SE})$ for total intramuscular androgen receptor protein content relative to total muscle protein content (ng/mg) for each condition are indicated in Figure 2 and Table 2. A $2 \times 2$ (Condition $(\mathrm{LL}, \mathrm{HL}) \times$ Time $(3 \mathrm{~h}$ Post-, $24 \mathrm{~h}$ Post-Exercise $))$, with pre-exercise as a covariate, factorial ANCOVA with repeated measures was used to account for differences in baseline values. The analysis indicated that no significant main effect for time $\left(\mathrm{F}=0.463, p=0.518, \eta^{2}=0.062\right)$, condition $(\mathrm{F}=2.290, p=0.174$, $\left.\eta^{2}=0.274\right)$ or significant time and condition interaction $\left(\mathrm{F}=0.372, p=0.561, \eta^{2}=0.030\right)$ were observed.

\subsection{Intramuscular Androgen Receptor-DNA Binding Activity.}

The mean $( \pm \mathrm{SE})$ for intramuscular androgen receptor-DNA binding relative to total nucleoplasmic muscle protein content (Abs/mg) for each condition are indicated in Figure 2 and Table 2. No significant main effect of time $\left(\mathrm{F}=1.475, p=0.225, \eta^{2}=0.141\right)$ or condition $\left(\mathrm{F}=1.406, p=0.266, \eta^{2}=0.135\right)$ for AR-DNA binding activity were observed. However, a significant interaction for time and condition $\left(\mathrm{F}=4.809, p=0.021, \eta^{2}=0.348\right)$ was observed. Analysis revealed that there was a significant increase in AR-DNA binding at $3 \mathrm{~h}$ post-exercise compared to pre-exercise in the HL condition $(p=0.030)$. 

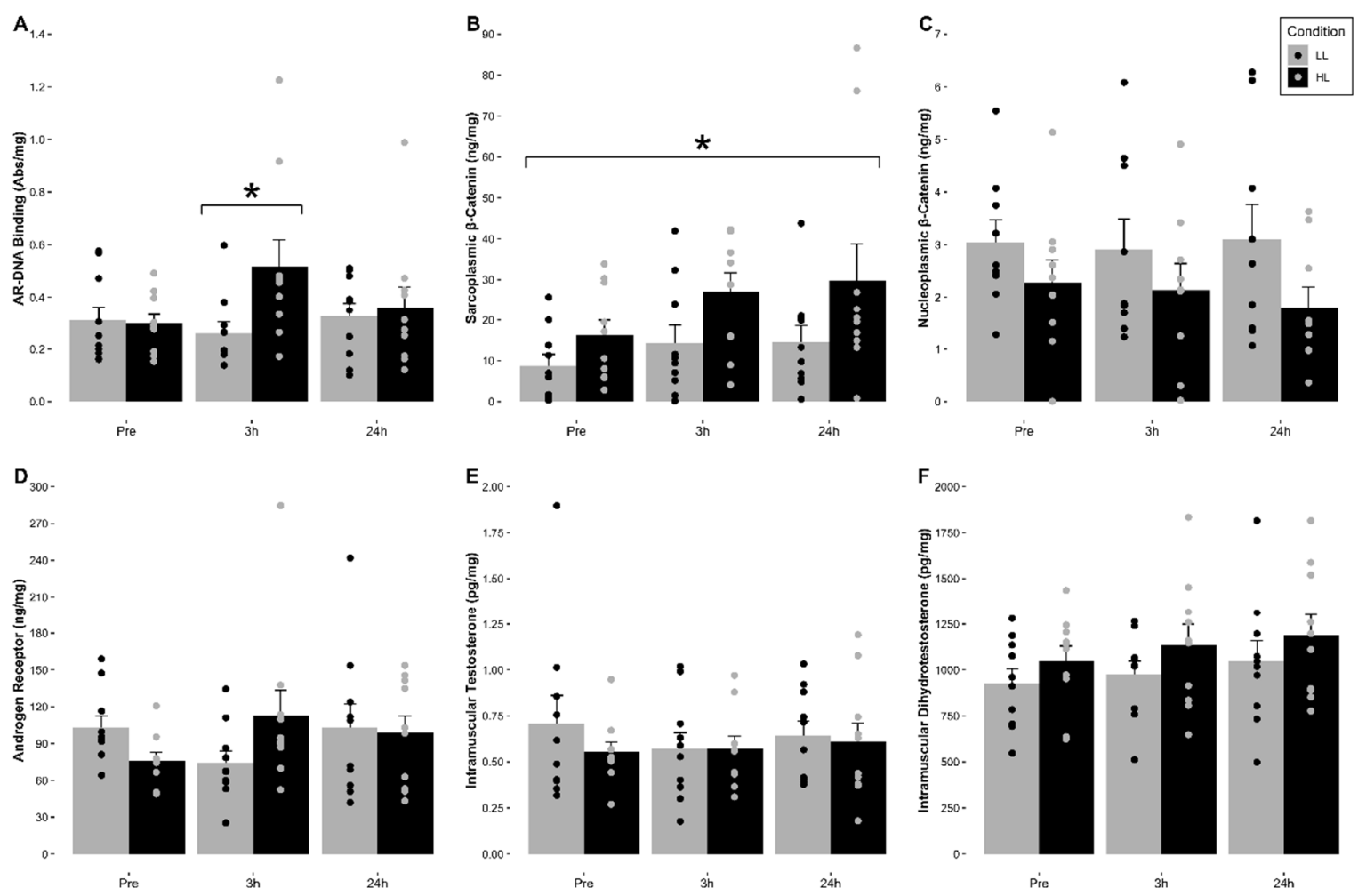

Figure 2. Mean $( \pm \mathrm{SE})$ and individual changes in (A) AR-DNA binding activity, (B) sarcoplasmic $\beta$-catenin, (C) nucleoplasmic $\beta$-catenin, (D) androgen receptor protein, (E) intramuscular testosterone, and (F) intramuscular dihydrotestosterone in response to volume- and intensity-equated low- and high-load resistance exercise. (A): * Indicates a significant increase in AR-DNA binding activity at $3 \mathrm{~h}$ post high-load resistance exercise $(p<0.05)$. (B): * Indicates a significant condition effect where high load was significantly greater than low load resistance exercise $(p<0.05)$. (C-F): There were no significant changes over time, between conditions, or significant interactions observed $(p>0.05)$.

\subsection{Intramuscular Sarcoplasmic and Nucleoplasmic $\beta$-Catenin Content}

The means $( \pm \mathrm{SE})$ for intramuscular sarcoplasmic and nucleoplasmic $\beta$-catenin for each condition are indicated in Figure 2 and Table 2. For the sarcoplasmic fraction, the Mauchly's test of sphericity indicated that there were violations in sphericity $(p=0.002)$ of the data. Therefore, a Greenhouse-Geisser adjustment was used to meet the needed assumptions to run the appropriate statistical analysis. No significant main effect for time $\left(\mathrm{F}=2.004, p=0.164, \eta^{2}=0.182\right)$ or significant time and condition interaction $\left(\mathrm{F}=0.504, p=0.513, \eta^{2}=0.053\right)$ for sarcoplasmic $\beta$-catenin content were observed. However, a significant main effect for condition where HL was significantly greater compared to LL when collapsed for time $\left(\mathrm{F}=5.414, p=0.045, \eta^{2}=0.376\right)$. Regarding nucleoplasmic $\beta$-catenin, no significant main effect for time $\left(F=0.054, p=0.948, \eta^{2}=0.011\right)$, condition $\left(F=1.600, p=0.262, \eta^{2}=0.242\right)$, or significant time and condition interaction $\left(\mathrm{F}=2.474, p=0.134, \eta^{2}=0.331\right)$ for nucleoplasmic $\beta$-catenin content were observed.

\section{Discussion}

This appears to be the first study investigating the effects of RE load in an intensity- and volume-equated manner on AR-DNA binding activity, AR protein content, the influence of the androgenic hormones, as well as both sarcoplasmic and nucleoplasmic $\beta$-catenin concentrations on AR signaling. It is generally thought that LL $(\leq 60 \% 1 \mathrm{RM})$ and $\mathrm{HL}(>60 \% 1 \mathrm{RM}) \mathrm{RE}$ have similar outcomes on skeletal muscle hypertrophy when performed to volitional muscular failure [51]. Therefore, the mechanisms which regulate skeletal muscle hypertrophy are also suggested to be identical in both LL and HL scenarios. In contrast to the prevailing theory, our data showed that HL full-body RE 
significantly increased ( $74 \%)$ AR-DNA binding at $3 \mathrm{~h}$ post-exercise compared to pre-exercise values. Moreover, this was not observed in the LL RE condition across all sampling times which indicates a potential load dependence in AR activation, translocation, and DNA binding. Interestingly, in response to both LL and HL conditions, we observed no significant changes in serum total testosterone, muscle testosterone or DHT concentrations, while serum-free testosterone was significantly decreased at $3 \mathrm{~h}$ post- (LL: $\sim 28 \%$ vs. HL: $\sim 20 \%$ ) and $24 \mathrm{~h}$ post-exercise (LL: $\sim 11 \%$ vs. HL: $\sim 6 \%$ ) compared to pre-exercise. Similarly, muscle testosterone and DHT concentrations did not significantly change suggesting the decrease/no change in serum-free and total testosterone concentrations did not affect skeletal muscle testosterone and DHT concentrations. Therefore, the observed increase in AR-DNA binding in the HL condition at $3 \mathrm{~h}$ post-exercise does not appear to be driven by load-mediated changes in either circulating and/or skeletal muscle androgen concentrations.

For its critical role in facilitating increases in AR signaling, the AR protein response may conceivably be mediating up-regulations in AR-DNA binding activity. However, we observed no significant changes in AR protein content across all time points in either condition. This suggests that our observed increases in AR signaling activity are not driven by changes in AR content. While more research is certainly warranted, this provides further evidence, along with others $[13,25,27,28]$, that AR protein content does not appear to acutely increase in response to RE and provides preliminary evidence that it may not be suggestive of upregulations in AR signaling or predictive of hypertrophic outcomes (AR protein response to chronic resistance training may be more indicative of hypertrophic outcomes; see [52]). Of particular interest, our data demonstrated time-independent, HL-specific greater concentrations of the AR co-activating protein $\beta$-catenin relative to LL. Specifically, skeletal muscle sarcoplasmic $\beta$-catenin concentrations were $\sim 94 \%$ greater in the HL condition versus the LL condition with no significant changes observed in the nucleoplasmic fraction. As a multifunctional protein shown to positively influence a number of processes (cell-cycle progression, cell-to-cell adhesion activity, and ribosome biogenesis) in addition to its ability to co-activate the AR, this load-mediated response provides further evidence of superior anabolic signaling activity in HL compared to LL RE [32,38,53]. Collectively, our findings indicate that, contrary to the current theory of load-mediated RE, AR-DNA binding and $\beta$-catenin activity are only increased after HL RE without concomitant increases in serum or muscle androgens or AR content.

The multifunctional Wnt-signaling protein, $\beta$-catenin, has been shown to robustly impact stability, activation, and transcriptional activity of the AR [32,54,55]. Theoretically, elevations in this AR co-activating protein directly increase AR activation, translocation, DNA binding, and result in up-regulations in muscle specific gene and eventual protein expression. As previously discussed, our data showed a significant increase in AR-DNA binding activity and greater sarcoplasmic $\beta$-catenin content in the absence of significant elevations in serum free and total testosterone, skeletal muscle testosterone and DHT, or AR protein content following HL RE. Considering that nucleoplasmic $\beta$-catenin did not appear to be significantly influenced, our data provide ostensible evidence that sarcoplasmic $\beta$-catenin may be playing a key regulatory role in encouraging AR-androgen interactions or activating the AR in an androgen-independent manner. Specifically, it appears as though this role is largely mediated through a novel undescribed HL-dependent mechanism that facilitates sarcoplasmic $\beta$-catenin accumulation ultimately increasing AR-protein interactions and facilitating AR-DNA binding within the nucleus. This phenomena also ostensibly contradicts the current theory denoting equivocal anabolic-signaling outcomes between HL and LL RE, and provides further evidence Wnt/ $\beta$-catenin signaling is responsive to mechanical loading [23,36,42]. However, this is the first study to propose this response may be dependent on the resistance or load placed on skeletal muscle.

There is considerable evidence of crosstalk between Wnt/ $\beta$-catenin and AR signaling in the literature $[35,38,39,55-58]$. $\beta$-catenin has been reported to activate the AR in both an androgen-dependent [54,55] and androgen-independent [35] manner. Previous in vitro and in vivo animal models offer inconclusive support in determining this potential androgen dependence of $\beta$-catenin-AR activity [54,55]. Lack of significant changes in muscle testosterone, DHT, or AR protein 
content with concomitant elevations in AR-DNA binding activity and greater sarcoplasmic $\beta$-catenin content alone does not provide sufficient evidence to make definitive mechanistic inferences about our data. Nevertheless, since we have demonstrated $\beta$-catenin's ability to accumulate in the sarcoplasm, with no changes within the nucleoplasm, we hypothesize our findings may be due to two primary mechanisms or a combination thereof including: (1) sarcoplasmic stabilization and co-activation of the AR-bound androgen by $\beta$-catenin and (2) sarcoplasmic androgen-independent activation of the AR by $\beta$-catenin (Figure 3) [35,36,54,55,59].



Figure 3. Sarcoplasmic androgen-dependent and androgen-independent AR activation by $\beta$-catenin. Two primary hypothetical mechanisms or a combination thereof posited to be associated with our findings: (1) sarcoplasmic stabilization and co-activation of the AR-bound androgen by $\beta$-catenin (A) and (2) sarcoplasmic androgen-independent activation of the AR by $\beta$-catenin $(B)$. AR = androgen receptor; LPR 5/6 = low-density lipoprotein receptor-related protein 5 or 6 ; FZD = frizzled receptor; Wnt = wingless-type mouse mammary tumor virus integration site $(\mathrm{Wnt})$ protein; DVL = disheveled; CK1 = casein kinase 1 ; GSK3 $\beta=$ glycogen synthase kinase $3 \beta$; FRAT = frequently rearranged in advanced $\mathrm{T}$ cell lymphomas; $\mathrm{ARE}=$ androgen response element).

While in vitro and in vivo animal models provide valuable insight into the potential molecular mechanisms governing this response, human models are more comparable given our study design. In a recent study by Spillane et al. [23], they investigated the $\beta$-catenin and AR signaling response to an acute bout of lower- and full-body RE. Also of relevance, this study design did not equate RE volume between the two conditions. Therefore, the full-body condition performed significantly more volume than the lower-body condition. Similar to our findings, they found increased AR-DNA binding activity and $\beta$-catenin content at $3 \mathrm{~h}$ post- and $24 \mathrm{~h}$ post-exercise, in addition to elevated serum Wnt 4 concentrations at 30 min post-, 1 h post-, and $2 \mathrm{~h}$ post-exercise, following the full-body RE bout. Consistent with our observations, no significant changes in serum-free and total testosterone or muscle testosterone and DHT were observed at any time point or condition. However, they did witness a significant increase in AR protein content at $3 \mathrm{~h}$ post- and a significant decrease at $24 \mathrm{~h}$ post-full body RE. Given that an increase in AR-DNA binding activity occurred at these time points, it further begs the question of whether the AR protein response is facilitating this acute increase in AR signaling activity. Given the incongruent AR protein and AR-DNA binding response in our study and that of Spillane et al. [23], we propose these observed acute elevations in AR signaling are not driven by 
changes in AR content. Rather, these data indicate up-regulations in Wnt $/ \beta$-catenin signaling may be facilitating increases in AR-DNA binding which appears reflective of elevations in AR signaling and potentially transcriptional activity. Furthermore, these data collectively suggest this response appears to be sensitive to load as well as the volume of mechanical work placed on skeletal muscle.

Previous research lends support to the notion that differential loading protocols do not dictate hypertrophy or increase AR signaling-related markers in skeletal muscle. A recent 12-week study by Morton et al. [12] concluded that LL (30-50\% $1 \mathrm{RM})$ and HL (75-90\% $1 \mathrm{RM})$ RE performed to volitional failure did not preferentially influence androgen hormone concentrations acutely or dictate skeletal muscle hypertrophy after 12-weeks. Similarly, our data demonstrate systemic and local androgen concentrations may not be significantly impacting AR signaling responses given the observed serum and muscle androgen-independent increase in AR-DNA binding. While the acute nature of our design prevents us from making definitive statements on hypertrophic outcomes and load, our data suggest a potential preferential anabolic response to HL RE as exhibited by the observed load-mediated increase in AR-DNA binding. Due to the overwhelming role volume and intensity play in RE-mediated hypertrophy, we speculate that the study design of Morton et al. [12] was unable to detect a preferential load response or lack thereof due to unequivocal RE volumes performed between HL and LL conditions $[45,60]$. Specifically, the HL condition only completed $\sim 62 \%$ of the total volume completed by the LL condition. By contrast, our design equated both volume and intensity of the different load conditions allowing for the acute effects of load to be carefully disseminated in the context of AR signaling and potential implications in skeletal muscle hypertrophy. Nevertheless, while this study does not demonstrate the effects of varying loads on practical hypertrophic outcomes, it corroborates our data and many others [52,61-64], providing evidence that systemic hormones are neither related to nor predictive of RE-induced changes in skeletal muscle mass in healthy young male participants.

In RE research, rarely is the effect of load on muscular adaptations examined without being affected by confounding variables such as volume and intensity. Previous research has clearly demonstrated the overwhelming influence volume and intensity have on skeletal muscle hypertrophy and the molecular responses that regulate these adaptations $[45,60]$. At this point, it appears this is the first study to control for these variables to accurately disseminate the effects of RE load on anabolic signaling pathways suggested to mediate skeletal muscle hypertrophy. The novelty in our study design limits our ability to speculate since no data seem to exist investigating the effects of RE load, in a volumeand intensity-equated manner, on markers of AR signaling. Nevertheless, our findings suggest a preferential load-dependent increase in AR signaling thought to be at least partially mediated through elevations in Wnt/ $\beta$-catenin-related signaling.

\section{Conclusions}

This appears to be the first study to date investigating the impacts of RE load, in a volume- and intensity-equated manner, on AR-DNA binding activity, serum and muscle androgen concentrations, AR protein content, and sarcoplasmic and nucleoplasmic $\beta$-catenin concentrations. In response to HL RE, we observed a significant $\sim 74 \%$ increase in AR-DNA binding activity without significant elevations in serum or muscle androgen concentrations or AR protein content. However, sarcoplasmic $\beta$-catenin content was $\sim 94 \%$ significantly greater when comparing the HL versus LL conditions regardless of time. Collectively, our findings provide evidence that when volume and intensity are equated, the acute AR signaling response to mechanical loading on skeletal muscle appears to be load-mediated. Moreover, the observed up-regulations in AR-DNA binding activity and greater sarcoplasmic $\beta$-catenin content suggest a preferential AR signaling response to HL RE. Our data further mechanistically support previous evidence of acute increases in AR signaling not being driven by changes in serum or muscle androgen concentrations nor AR protein content. Rather, AR co-activating proteins, such as $\beta$-catenin, may be largely responsible for mediating this response. Unfortunately, we cannot infer causality with the current dataset, considering the (time $\times$ condition) interaction effect observed in 
AR-DNA binding at $3 \mathrm{~h}$ was not mirrored by the observed condition-only effect in sarcoplasmic $\beta$-catenin. Furthermore, an inability to randomize study conditions to equate volume and intensity and a relatively small sample size are both clear limitations and must be considered when interpreting our findings. Many questions still remain about a variety of factors driving the acute AR signaling response to RE. Better understanding of molecular mechanisms in which AR co-activating proteins, such as $\beta$-catenin, interact with the AR may allow for more clarity and provide the necessary context to better explain these occurrences. Future research should investigate the impacts of other AR co-activating proteins and determine their differential impacts on the acute AR signaling response and, by extension, hypertrophic outcomes in skeletal muscle.

Author Contributions: Conceptualization, T.D.C. and D.S.W.; Methodology, T.D.C. and D.S.W.; Formal analysis, T.D.C., S.B.M., D.T.W., J.L.H. and D.S.W.; Investigation, T.D.C., S.B.M., D.T.W., J.L.H. and D.S.W.; Resources, T.D.C. and D.S.W.; Data curation, T.D.C., S.B.M., D.T.W., J.L.H. and D.S.W.; Writing-original draft preparation, T.D.C. and D.S.W.; Writing-review and editing, T.D.C., S.B.M., D.T.W., J.L.H. and D.S.W.; Project administration, T.D.C. and D.S.W.; Funding acquisition, T.D.C. and D.S.W. All authors have read and agreed to the published version of the manuscript.

Funding: This research was funded by the American College of Sports Medicine-Texas Chapter, Student Research Development Grant and the Baylor University Health, Human Performance, and Recreation Graduate Student Research Grant.

Acknowledgments: The authors would like to acknowledge Emma Fletcher, Harry Cintineo, Dillon Harris, and Justin Shahtout for their contributions.

Conflicts of Interest: The authors declare no conflict of interest.

\section{References}

1. Fink, J.; Schoenfeld, B.J.; Nakazato, K. The role of hormones in muscle hypertrophy. Physician Sportsmed. 2018, 46, 129-134. [CrossRef] [PubMed]

2. Grino, P.B.; Griffin, J.E.; Wilson, J.D. Testosterone at High Concentrations Interacts with the Human Androgen Receptor Similarly to Dihydrotestosterone. Endocrinology 1990, 126, 1165-1172. [CrossRef] [PubMed]

3. Denayer, S.; Helsen, C.; Thorrez, L.; Haelens, A.; Claessens, F. The Rules of DNA Recognition by the Androgen Receptor. Mol. Endocrinol. 2010, 24, 898-913. [CrossRef] [PubMed]

4. Roberts, M.D.; Dalbo, V.J.; E Hassell, S.; Kerksick, C.M. The Expression of Androgen-Regulated Genes Before and After a Resistance Exercise Bout in Younger and Older Men. J. Strength Cond. Res. 2009, 23, 1060-1067. [CrossRef]

5. Kicman, A.T. Biochemical and Physiological Aspects of Endogenous Androgens. Bone Regul. Osteoporos. Ther. 2009, 195, 25-64.

6. Ahtiainen, J.P.; Hulmi, J.; Kraemer, W.J.; Lehti, T.M.; Nyman, K.; Selänne, H.; Alén, M.; Pakarinen, A.; Komulainen, J.; Kovanen, V.; et al. Heavy resistance exercise training and skeletal muscle androgen receptor expression in younger and older men. Steroids 2011, 76, 183-192. [CrossRef]

7. Ahtiainen, J.P.; Pakarinen, A.; Kraemer, W.J.; Häkkinen, K. Acute Hormonal Responses to Heavy Resistance Exercise in Strength Athletes Versus Nonathletes. Can. J. Appl. Physiol. 2004, 29, 527-543. [CrossRef]

8. Cadore, E.L.; Lhullier, F.L.R.; Brentano, M.A.; Da Silva, E.M.; Ambrosini, M.B.; Spinelli, R.; Silva, R.F.; Kruel, L.F.M. Hormonal Responses to Resistance Exercise in Long-Term Trained and Untrained Middle-Aged Men. J. Strength Cond. Res. 2008, 22, 1617-1624. [CrossRef]

9. Hakkinen, K.; Pakarinen, A. Acute hormonal responses to two different fatiguing heavy-resistance protocols in male athletes. J. Appl. Physiol. 1993, 74, 882-887. [CrossRef]

10. Kraemer, W.J.; Gordon, S.E.; Fleck, S.J.; Marchitelli, L.J.; Mello, R.; Dziados, J.E.; Friedl, K.; Harman, E.; Maresh, C.; Fry, A.C. Endogenous Anabolic Hormonal and Growth Factor Responses to Heavy Resistance Exercise in Males and Females. Int. J. Sports Med. 1991, 12, 228-235. [CrossRef]

11. Kraemer, W.J.; Marchitelli, L.; Gordon, S.E.; Harman, E.; Dziados, J.E.; Mello, R.; Frykman, P.; McCurry, D.; Fleck, S.J. Hormonal and growth factor responses to heavy resistance exercise protocols. J. Appl. Physiol. 1990, 69, 1442-1450. [CrossRef] [PubMed]

12. Morton, R.W.; Oikawa, S.Y.; Wavell, C.G.; Mazara, N.; McGlory, C.; Quadrilatero, J.; Baechler, B.L.; Baker, S.K.; Phillips, S.M. Neither load nor systemic hormones determine resistance training-mediated hypertrophy or strength gains in resistance-trained young men. J. Appl. Physiol. 2016, 121, 129-138. [CrossRef] [PubMed] 
13. Spiering, B.A.; Kraemer, W.J.; Vingren, J.L.; Ratamess, N.A.; Anderson, J.M.; Armstrong, L.E.; Nindl, B.C.; Volek, J.S.; Häkkinen, K.; Maresh, C.M. Elevated endogenous testosterone concentrations potentiate muscle androgen receptor responses to resistance exercise. J. Steroid Biochem. Mol. Biol. 2009, 114, 195-199. [CrossRef] [PubMed]

14. Vingren, J.L.; Kraemer, W.J.; Hatfield, D.L.; Anderson, J.M.; Volek, J.S.; Ratamess, N.A.; Thomas, G.A.; Ho, J.-Y.; Fragala, M.S.; Maresh, C.M. Effect of resistance exercise on muscle steroidogenesis. J. Appl. Physiol. 2008, 105, 1754-1760. [CrossRef]

15. Walker, S.; Taipale, R.S.; Nyman, K.; Kraemer, W.J.; Häkkinen, K. Neuromuscular and Hormonal Responses to Constant and Variable Resistance Loadings. Med. Sci. Sports Exerc. 2011, 43, 26-33. [CrossRef]

16. West, D.W.D.; Kujbida, G.W.; Moore, D.R.; Atherton, P.; Burd, N.A.; Padzik, J.P.; De Lisio, M.; Tang, J.E.; Parise, G.; Rennie, M.J.; et al. Resistance exercise-induced increases in putative anabolic hormones do not enhance muscle protein synthesis or intracellular signalling in young men. J. Physiol. 2009, 587, 5239-5247. [CrossRef]

17. Willoughby, D.S.; Taylor, L. Effects of Sequential Bouts of Resistance Exercise on Androgen Receptor Expression. Med. Sci. Sports Exerc. 2004, 36, 1499-1506. [CrossRef]

18. Bamman, M.M.; Shipp, J.R.; Jiang, J.; Gower, B.A.; Hunter, G.R.; Goodman, A.; McLafferty, C.L.; Urban, R.J. Mechanical load increases muscle IGF-I and androgen receptor mRNA concentrations in humans. Am. J. Physiol. Metab. 2001, 280, E383-E390. [CrossRef]

19. Fry, A.C.; Lohnes, C.A. Acute testosterone and cortisol responses to high power resistance exercise. Hum. Physiol. 2010, 36, 457-461. [CrossRef]

20. Gonzalez, A.M.; Hoffman, J.R.; Townsend, J.R.; Jajtner, A.R.; Boone, C.H.; Beyer, K.S.; Baker, K.M.; Wells, A.J.; Mangine, G.T.; Robinson, E.H.; et al. Intramuscular anabolic signaling and endocrine response following high volume and high intensity resistance exercise protocols in trained men. Physiol. Rep. 2015, 3, e12466. [CrossRef]

21. Goto, K.; Maemura, H.; Takamatsu, K.; Ishii, N. Hormonal Responses to Resistance Exercise after Ingestion of Carnosine and Anserine. J. Strength Cond. Res. 2011, 25, 398-405. [CrossRef] [PubMed]

22. Harber, M.P.; Fry, A.C.; Rubin, M.R.; Smith, J.C.; Weiss, L.W. Skeletal muscle and hormonal adaptations to circuit weight training in untrained men. Scand. J. Med. Sci. Sports 2004, 14, 176-185. [CrossRef] [PubMed]

23. Spillane, M.; Schwarz, N.; Willoughby, D. Upper-body resistance exercise augments vastus lateralis androgen receptor-DNA binding and canonical Wnt/ $\beta$-catenin signaling compared to lower-body resistance exercise in resistance-trained men without an acute increase in serum testosterone. Steroids 2015, 98, 63-71. [CrossRef] [PubMed]

24. Wu, B.-H.; Lin, J.-C. Caffeine Attenuates Acute Growth Hormone Response to a Single Bout of Resistance Exercise. J. Sports Sci. Med. 2010, 9, 262-269.

25. Lee, W.J.; Thompson, R.W.; McClung, J.M.; Carson, J.A. Regulation of androgen receptor expression at the onset of functional overload in rat plantaris muscle. Am. J. Physiol. Integr. Comp. Physiol. 2003, 285, R1076-R1085. [CrossRef] [PubMed]

26. Hulmi, J.; Ahtiainen, J.P.; Selänne, H.; Volek, J.S.; Häkkinen, K.; Kovanen, V.; Mero, A.A. Androgen receptors and testosterone in men-Effects of protein ingestion, resistance exercise and fiber type. J. Steroid Biochem. Mol. Biol. 2008, 110, 130-137. [CrossRef]

27. Ratamess, N.A.; Kraemer, W.J.; Volek, J.S.; Maresh, C.M.; VanHeest, J.L.; Sharman, M.J.; Rubin, M.R.; French, D.N.; Vescovi, J.D.; Silvestre, R.; et al. Androgen receptor content following heavy resistance exercise in men. J. Steroid Biochem. Mol. Biol. 2005, 93, 35-42. [CrossRef]

28. Vingren, J.L.; Kraemer, W.J.; Hatfield, D.L.; Volek, J.S.; Ratamess, N.A.; Anderson, J.M.; Häkkinen, K.; Ahtiainen, J.P.; Fragala, M.S.; Thomas, G.A. Effect of resistance exercise on muscle steroid receptor protein content in strength-trained men and women. Steroids 2009, 74, 1033-1039. [CrossRef]

29. Kim, H.J.; Lee, W.J. Insulin-like growth factor-I induces androgen receptor activation in differentiating $\mathrm{C} 2 \mathrm{C} 12$ skeletal muscle cells. Mol. Cells 2009, 28, 189-194. [CrossRef]

30. Ueda, T.; Mawji, N.R.; Bruchovsky, N.; Sadar, M.D. Ligand-independent Activation of the Androgen Receptor by Interleukin-6 and the Role of Steroid Receptor Coactivator-1 in Prostate Cancer Cells. J. Biol. Chem. 2002, 277, 38087-38094. [CrossRef]

31. Weigel, N.L.; Zhang, Y. Ligand-independent activation of steroid hormone receptors. J. Mol. Med. 1998, 76, 469-479. [CrossRef] [PubMed] 
32. Mulholland, D.J.; Dedhar, S.; Coetzee, G.A.; Nelson, C.C. Interaction of Nuclear Receptors with the Wnt/ß-Catenin/Tcf Signaling Axis: Wnt You Like to Know? Endocr. Rev. 2005, 26, 898-915. [CrossRef] [PubMed]

33. Kypta, R.M.; Waxman, J. Wnt/ß-catenin signalling in prostate cancer. Nat. Rev. Urol. 2012, 9, 418-428. [CrossRef] [PubMed]

34. Song, D.H.; Dominguez, I.; Mizuno, J.; Kaut, M.; Mohr, S.C.; Seldin, D.C. CK2 Phosphorylation of the Armadillo Repeat Region of $\beta$-Catenin Potentiates Wnt Signaling. J. Biol. Chem. 2003, 278, 24018-24025. [CrossRef]

35. Wang, G.; Wang, J.; Sadar, M.D. Crosstalk between the Androgen Receptor and-Catenin in Castrate-Resistant Prostate Cancer. Cancer Res. 2008, 68, 9918-9927. [CrossRef] [PubMed]

36. Armstrong, D.D.; Esser, K.A. Wnt/ $\beta$-catenin signaling activates growth-control genes during overload-induced skeletal muscle hypertrophy. Am. J. Physiol. Physiol. 2005, 289, C853-C859. [CrossRef]

37. Mumford, P.W.; Romero, M.A.; Mao, X.; Mobley, C.B.; Kephart, W.C.; Haun, C.T.; Roberson, P.A.; Young, K.C.; Martin, J.S.; Yarrow, J.F.; et al. Cross talk between androgen and Wnt signaling potentially contributes to age-related skeletal muscle atrophy in rats. J. Appl. Physiol. 2018, 125, 486-494. [CrossRef]

38. Newmire, D.; Willoughby, D.S. Wnt and $\beta$-Catenin Signaling and Skeletal Muscle Myogenesis in Response to Muscle Damage and Resistance Exercise and Training. Int. J. Kinesiol. Sports Sci. 2015, 3, 40-49. [CrossRef]

39. Zhuo, M.; Zhu, C.; Sun, J.; Weis, W.I.; Sun, Z. The $\beta$-Catenin Binding Protein ICAT Modulates Androgen Receptor Activity. Mol. Endocrinol. 2011, 25, 1677-1688. [CrossRef]

40. Pratt, W.B.; Toft, D.O. Steroid Receptor Interactions with Heat Shock Protein and Immunophilin Chaperones. Endocr. Rev. 1997, 18, 306-360. [CrossRef]

41. Wang, X.; Goode, E.L.; Fredericksen, Z.S.; Vierkant, R.A.; Pankratz, V.S.; Liu-Mares, W.; Rider, D.N.; Vachon, C.M.; Cerhan, J.R.; Olson, J.E.; et al. Association of genetic variation in genes implicated in the beta-catenin destruction complex with risk of breast cancer. Cancer Epidemiol. Biomark. Prev. 2008, 17, 2101-2108. [CrossRef] [PubMed]

42. Leal, M.L.; Lamas, L.; Aoki, M.S.; Ugrinowitsch, C.; Ramos, M.S.C.; Tricoli, V.; Moriscot, A.S. Effect of different resistance-training regimens on the WNT-signaling pathway. Graefe's Arch. Clin. Exp. Ophthalmol. 2011, 111, 2535-2545. [CrossRef] [PubMed]

43. Haff, G.G.; Triplett, N.T. Administration, Scoring, and Interpretation of Selected Tests. In Essentials of Strength Training and Conditioning; Human Kinetics: Champaign, IL, USA, 2016; pp. 259-316.

44. Cintineo, H.P.; Freidenreich, D.J.; Blaine, C.M.; Cardaci, T.D.; Pellegrino, J.K.; Arent, S.M. Acute Physiological Responses to an Intensity-And Time-Under-Tension-Equated Single vs. Multiple-Set Resistance Training Bout in Trained Men. J. Strength Cond. Res. 2018, 32, 3310-3318. [CrossRef] [PubMed]

45. Kraemer, W.J.; Ratamess, N.A. Fundamentals of Resistance Training: Progression and Exercise Prescription. Med. Sci. Sports Exerc. 2004, 36, 674-688. [CrossRef] [PubMed]

46. Strength to Weight Ratios Age-Gender Norms 1RM Bench Press and Leg Press. In The Physical Fitness Specialist Certification Manual; The Cooper Institute for Aerobics Research: Dallas, TX, USA, 1997.

47. Wax, B.; Brown, S.P.; Webb, H.E.; Kavazis, A.N.; Kinzey, S. Effects of Carbohydrate Supplementation on Force Output and Time to Exhaustion During Static Leg Contractions Superimposed with Electromyostimulation. J. Strength Cond. Res. 2012, 26, 1717-1723. [CrossRef] [PubMed]

48. Judelson, D.A.; Maresh, C.M.; Yamamoto, L.M.; Farrell, M.J.; Armstrong, L.E.; Kraemer, W.J.; Volek, J.S.; Spiering, B.A.; Casa, D.J.; Anderson, J.M. Effect of hydration state on resistance exercise-induced endocrine markers of anabolism, catabolism, and metabolism. J. Appl. Physiol. 2008, 105, 816-824. [CrossRef]

49. Cardaci, T.D.; Machek, S.B.; Wilburn, D.T.; Hwang, P.S.; Willoughby, D.S. Ubiquitin Proteasome System Activity is Suppressed by Curcumin following Exercise-Induced Muscle Damage in Human Skeletal Muscle. J. Am. Coll. Nutr. 2020, 1-11. [CrossRef]

50. Bakeman, R. Recommended effect size statistics for repeated measures designs. Behav. Res. Methods 2005, 37, 379-384. [CrossRef]

51. Schoenfeld, B.J.; Grgic, J.; Ogborn, D.; Krieger, J.W. Strength and Hypertrophy Adaptations Between Low vs. High-Load Resistance Training: A Systematic Review and Meta-analysis. J. Strength Cond. Res. 2017, 31, 3508-3523. [CrossRef]

52. Morton, R.W.; Sato, K.; Gallaugher, M.P.B.; Oikawa, S.Y.; McNicholas, P.D.; Fujita, S.; Phillips, S.M. Muscle Androgen Receptor Content but Not Systemic Hormones Is Associated with Resistance Training-Induced Skeletal Muscle Hypertrophy in Healthy, Young Men. Front. Physiol. 2018, 9, 1373. [CrossRef] 
53. Chaillou, T.; Kirby, T.J.; McCarthy, J.J. Ribosome Biogenesis: Emerging Evidence for a Central Role in the Regulation of Skeletal Muscle Mass. J. Cell. Physiol. 2014, 229, 1584-1594. [CrossRef] [PubMed]

54. Yang, F.; Li, X.; Sharma, M.; Sasaki, C.Y.; Longo, D.L.; Lim, B.; Sun, Z. Linking $\beta$-Catenin to Androgen-signaling Pathway. J. Biol. Chem. 2002, 277, 11336-11344. [CrossRef] [PubMed]

55. Truica, C.I.; Byers, S.; Gelmann, E.P. Beta-catenin affects androgen receptor transcriptional activity and ligand specificity. Cancer Res. 2000, 60, 4709-4713. [PubMed]

56. Mulholland, D.J.; Cheng, H.; Reid, K.; Rennie, P.S.; Nelson, C.C. The Androgen Receptor Can Promote $\beta$-Catenin Nuclear Translocation Independently of Adenomatous Polyposis Coli. J. Biol. Chem. 2002, 277, 17933-17943. [CrossRef] [PubMed]

57. Pawlowski, J.E.; Ertel, J.R.; Allen, M.P.; Xu, M.; Butler, C.; Wilson, E.M.; E Wierman, M. Liganded Androgen Receptor Interaction with $\beta$-Catenin. J. Biol. Chem. 2002, 277, 20702-20710. [CrossRef] [PubMed]

58. Singh, R.; Bhasin, S.; Braga, M.; Artaza, J.N.; Pervin, S.; Taylor, W.E.; Krishnan, V.; Sinha, S.K.; Rajavashisth, T.B.; Jasuja, R. Regulation of Myogenic Differentiation by Androgens: Cross Talk between Androgen Receptor/ $\beta$-Catenin and Follistatin/Transforming Growth Factor- $\beta$ Signaling Pathways. Endocrinology 2009, 150, 1259-1268. [CrossRef]

59. Henderson, B.R. Nuclear-cytoplasmic shuttling of APC regulates $\beta$-catenin subcellular localization and turnover. Nat. Cell Biol. 2000, 2, 653-660. [CrossRef]

60. Schoenfeld, B.J.; Contreras, B.; Krieger, J.; Grgic, J.; Delcastillo, K.; Belliard, R.; Alto, A. Resistance Training Volume Enhances Muscle Hypertrophy but Not Strength in Trained Men. Med. Sci. Sports Exerc. 2019, 51, 94-103. [CrossRef]

61. West, D.W.D.; Burd, N.A.; Tang, J.E.; Moore, D.R.; Staples, A.W.; Holwerda, A.M.; Baker, S.K.; Phillips, S.M. Elevations in ostensibly anabolic hormones with resistance exercise enhance neither training-induced muscle hypertrophy nor strength of the elbow flexors. J. Appl. Physiol. 2010, 108, 60-67. [CrossRef]

62. West, D.W.D.; Phillips, S.M. Associations of exercise-induced hormone profiles and gains in strength and hypertrophy in a large cohort after weight training. Graefe's Arch. Clin. Exp. Ophthalmol. 2012, 112, 2693-2702. [CrossRef]

63. Mitchell, C.J.; Churchward-Venne, T.A.; Bellamy, L.; Parise, G.; Baker, S.K.; Phillips, S.M. Muscular and Systemic Correlates of Resistance Training-Induced Muscle Hypertrophy. PLoS ONE 2013, 8, e78636. [CrossRef] [PubMed]

64. Mobley, C.B.; Haun, C.T.; Roberson, P.A.; Mumford, P.W.; Kephart, W.C.; Romero, M.A.; Osburn, S.C.; Vann, C.G.; Young, K.C.; Beck, D.T.; et al. Biomarkers associated with low, moderate, and high vastus lateralis muscle hypertrophy following 12 weeks of resistance training. PLoS ONE 2018, 13, e0195203. [CrossRef] [PubMed]

Publisher's Note: MDPI stays neutral with regard to jurisdictional claims in published maps and institutional affiliations.

(C) 2020 by the authors. Licensee MDPI, Basel, Switzerland. This article is an open access article distributed under the terms and conditions of the Creative Commons Attribution (CC BY) license (http://creativecommons.org/licenses/by/4.0/). 